\title{
GRAMATIKA DALAM WACANA KONFLIK KPK VS POLRI JILID II
}

\section{(Gramatika in the Discourse of Conflict between Corruption Eradication Comission (KPK) Vs Indonesian National Police (Polri) Part II)}

\author{
Endro Nugroho Wasono Aji \\ Balai Bahasa Provinsi Jawa Tengah \\ Jalan Elang Raya No. 1, Mangunharjo, Tembalang, Semarang \\ Telepon 024-76744357, 70769945; Faksimile 024-7674358, 70799945 \\ Pos-el: wasono_ajie@yahoo.com \\ Diterima; 26 Januari 2018; Direvisi: 25 Juni 2018; Disetujui; 25 Juni 2018
}

\begin{abstract}
Language is used by a person, group, or institution for its purposes. Such interests are hidden in the lingual features. One of them in grammar. It also appears in editorial published by Suara Merdeka newspaper in discussing the conflict of KPK vs Police part II. This paper discusses how the perspective of Suara Merdeka is in conflict between KPK vs Police part II by using critical discourse analysis model Norman Fairclough. Based on the grammatical using of transitivity, nominalization, passive active-passive choice, positive-negative sentence choice, and modality the editor of Suara Merdeka place the institution of KPK as the victim (the wrong party). On the contrary, on the other side, the editor describes the position of the Police as the dominating party and marginalizing the president's position in the conflict. Thus, the perspective of Suara Merdeka in KPK vs Police Volume II conflict tends to favor to the institution of KPK.
\end{abstract}

Keywords: critical discourse analysis; grammar; and ideology

\begin{abstract}
Abstrak
Bahasa digunakan oleh seseorang, kelompok, atau institusi untuk kepentingannya. Kepentingan tersebut tersembunyi dalam fitur-fitur lingual. Salah satunya dalam gramatika. Hal tersebut juga tampak dalam tajuk rencana yang ditulis harian Suara Merdeka dalam membahas konflik KPK vs Polri jilid II. Artikel ini membahas bagaimana pandangan harian Suara Merdeka dalam konflik KPK vs Polri jilid II dengan menggunakan analisis wacana kritis model Norman Fairclough. Berdasarkan gramatikanya dengan memanfaatkan transitivitas, nominalisasi, pilihan kalimat aktif-pasif, pilihan kalimat positif-negatif, dan modalitas redaksi Suara Merdeka menempatkan institusi KPK sebagai korban (pihak yang dizalimi). Sebaliknya, di pihak lain redaksi menggambarkan posisi Polri sebagai pihak yang mendominasi dan memarjinalkan posisi presiden dalam konflik tersebut. Dengan demikian, pandangan harian Suara Merdeka dalam konflik KPK vs Polri jilid II cenderung berpihak pada institusi KPK.
\end{abstract}

Kata kunci: analisis wacana kritis; gramatika; dan ideologi

\section{PENDAHULUAN}

Bahasa seringkali digunakan seseorang, kelompok, atau institusi untuk kepentingannya. Kepentingan tersebut tersembunyi dalam bahasa yang tersusun dalam struktur-struktur lingual tertentu sehingga orang tidak menyadari adanya muatan-muatan kekuasaan dan ideologi yang samar. Struktur kebahasaan tersebut digunakan oleh penghasil teks untuk menyistematisasikan, mentransformasikan, dan bahkan seringkali mengaburkan realitas. Struktur kebahasaan juga digunakan oleh penghasil teks untuk mengatur ide dan perilaku orang lain. Selain itu, juga digunakan untuk mengklasifikasikan, mengelompokkan, dan menggolongkan masyarakat, peristiwa, serta objek-objek untuk 
menegaskan status institusional dan personal. Dengan kata lain, bahasa telah berkembang menjadi peranti kekuasaan yang efektif (Rokhman dan Surahmat, 2016: vii). Berhubung sifatnya yang tersembunyi, tugas analisis wacana kritis untuk mengungkap ideologi agar menjadi jelas bagi konsumen atau penerima teks. Ideologi yang disembunyikan melekat pada fitur kebahasaan atau fitur lingual. Oleh karena itu, untuk mengungkap relasi kuasa dan ideologi dapat diawali dari analisis fitur-fitur lingual.

Analisis wacana kritis pada hakikatnya mengkaji bahasa secara kritis. Mengkaji bahasa secara kritis dilakukan dengan menganalisis aspek-aspek kebahasaan atau fitur-fitur lingual secara kritis. Selanjutnya, analisis wacana kritis menemukan penjelasan mengapa penghasil teks memilih bentuk-bentuk lingual itu. Melalui penjelasan tersebut, dapat diketahui ideologi yang diyakini dan diperjuangkan oleh penghasil teks (Santoso, 2012:137).

Kajian wacana kritis dapat dikatakan sebagai sebuah kajian yang relatif baru. Namun, kajian tersebut sudah banyak dilakukan. Kajian tersebut berupa artikel-artikel yang dimuat di jurnal kebahasaan, antara lain, artikel Rambe (2012), Tahmasbi dan Khalkajeh (2013), Sutrisno (2012), dan Mardikantoro (2014).

Rambe (2012) menulis artikel berjudul "Critical Discourse Analysis of Collaborative Engagement in Facebook Postings". Dengan menggunakan analisis wacana kritis model Fairclough diungkap beberapa asumsi tersembunyi tentang kekuasaan dan ideologi implisit di balik praktik diskursif yang diartikulasikan melalui Facebook. Lewat deskripsi, interpretasi, dan ekplanasi teks, hubungan antara teks dan konteks sosial yang lebih luas menjadi lebih jelas. Dalam simpulannya, Rambe menyatakan bahwa wacana menjadi manipulatif ketika penerima (pembaca) tidak dapat memahami maksud sebenarnya pengirim (penulis) atau konsekuensi dari keyakinan atau tindakan manipulator. Hal ini sering terjadi terutama ketika penerima tidak memiliki pengetahuan khusus yang dapat digunakan untuk melawan manipulasi.

Analisis wacanakritis dengan menggunakan pendekatan tiga dimensi Fairclough juga ditulis oleh Tahmasbi dan Khalkajeh (2013) di jurnal Asian Economic and Financial Review dengan judul "Critical Discourse Analysis: Iranian Banks Advertisements". Kajian ini mencoba menganalisis iklan bank dalam konteks sosiokultural di Iran. Dengan menggunakan kerangka kerja tiga dimensi teks Fairclough yang berkaitan erat yang disebut (1) deskripsi teks, (2) interpretasi produksi dan konsumsi teks, dan (3) eksplanasi. Temuan dari kajian ini mengungkap analisis wacana kritis dapat mendeteksi teks manipulatif bahasa iklan yang menggunakan nilai budaya, sosial, dan ideologi dan meyakinkan orang untuk memercayainya.

Relevansi kajian Rambe, Tahmasbi dan Khalkajeh dengan kajian ini terletak pada model analisis yang digunakan yaitu analisis wacana kritis model Norman Fairclough. Perbedaannya terletak pada objek kajian yang dipilih. Rambe mengkaji wacana di media sosial Facebook. Adapun, artikel Tahmasbi dan Khalkajeh mengkaji wacana iklan bank, sedangkan artikel ini mengkaji wacana tajuk rencana yang terdapat dalam harian Suara Merdeka.

Selain artikel-artikel yang dimuat di jurnal internasional, artikel dengan menggunakan analisis wacana kritis juga banyak ditulis di jurnal nasional, di antaranya ditulis oleh Sutrisno (2012) dan Mardikantoro (2014).

Sutrisno (2012) menulis artikel yang berjudul "Editorial Media Indonesia dan Tajuk Rencana Kompas dalam Analisis Wacana Kritis". Dalam tulisannya tersebut, Sutrisno menyatakan bahwa dalam tajuk rencana Kompas dan editorial Media Indonesia bekerja konsep kekuasaan, konsep ideologi, dan konsep sejarah walaupun implisit ketiganya mengemuka cukup jelas. Editor Media Indonesia lebih ekspresif, bebas, dominan berpihak pada rakyat atau publik. Sementara, tajuk rencana Kompas relatif lebih netral bahkan dalam beberapa hal menunjukkan keberpihakan pada pemerintah 
dengan cara mengurangi ekspresivitas penyampaian. Kecederungan itu mengemuka pada beberapa aspek tekstual yang menonjol, yaitu: penggunaan kosakata, struktur frasa dan kalimat, serta struktur teks.

Sementara itu, dalam jurnal Litera Mardikantoro (2014) menyimpulkan bahwa harian Suara Merdeka memiliki sikap dan pandangan setuju dan mendukung berita korupsi di surat kabar. Dukungan tersebut mengacu pada upaya pemberantasan korupsi yang dapat diwujudkan dalam penangkapan tersangka koruptor, persidangan, dan vonis hukuman terhadap tersangka koruptor.

Dari dua kajian (Sutrisno dan Mardikantoro) terhadap tajuk rencana atau editorial harian di atas terlihat kecenderungan keberpihakan media massa pada pihak-pihak tertentu. Fenomena tersebut juga terlihat pada wacana tajuk rencana di harian Suara Merdeka yang membahas konflik KPK vs Polri jilid II. Aspek-aspek kebahasaan atau fitur-fitur lingual digunakan untuk menggambarkan realitas yang diinginkan redaksi. Aspek-aspek kebahasaan yang digunakan berupa kosakata, gramatika, dan struktur teks. Berhubung keterbatasan tempat, artikel ini hanya membahas gramatika sebagai pembawa ideologi. Adapun ideologi yang dimaksud dalam tulisan ini adalah sistem nilai atau gagasan yang dimiliki oleh kelompok atau lapisan masyarakat tertentu termasuk prosesproses yang bersifat umum dalam produksimakna dan gagasan (Darma, 2009: 56). Dalam hal ini, ideologi berupa gagasan yang tercermin dalam pandangan-pandangan redaksi Suara Merdeka dalam menyikapi konflik atau perseteruan KPK versus Polri jilid II. Penelitian ini bertujuan untuk mendeskripsikan pandangan-pandangan redaksi Suara Merdeka dalam konflik KPK vs Polri jilid II yang tercermin dari penggunaan gramatika.

\section{KERANGKA TEORI}

Artikel ini menggunakan analisis wacana kritis dalam kajiannya. Analisis wacana kritis adalah a study of relations between discourse, power, dominance, social inequality, and the position of the discourse analysis in such social relation (van Dijk, 2001:300). Analisis wacana kritis mengkaji hubungan-hubungan antara kekuasaan, dominasi, ketidakadilan sosial, dan posisi analis wacana dalam sebuah hubungan sosial. Adapun analisis wacana kritis yang digunakan dalam tulisan ini adalah analisis wacana kritis model Norman Fairclough. Menurut Fairclough ada tiga elemen dalam analisis wacana kritis, yaitu deskripsi teks, interpretasi teks (dalam hubungannya dengan teks dan interaksi), dan eksplanasi (dalam hubungan antara interaksi dan konteks sosial) (Fairclough, 2003: 125). Prosedur analisis wacana kritis digambarkan Fairclough sebagai berikut.

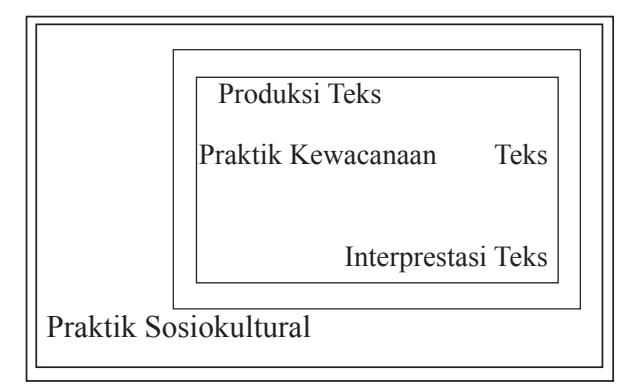

Gambar 1 Kerangka Analisis Wacana Kritis Model Fairclough

Deskripsi merupakan tingkatan yang berhubungan dengan sifat formal teks. Dalam model Fairclough teks dianalisis secara linguistik dengan melihat kosakata, gramatika, dan struktur teks. Ada lima hal yang berkaitan dengan gramatika dalam sebuah teks, yaitu ketransitifan, nominalisasi, pilihan kalimat aktif-pasif, pilihan kalimat positif-negatif, dan modalitas. Berikut ini penjelasan kelima hal tersebut.

\section{Ketransitifan}

Perbedaan dalam memilih ketransitifan sebuah kalimat berakibat pada perbedaan pandangan dunia. Menurut Fowler (dalam Santoso, 2012: 152) ketransitifan dibagi ke dalam tiga tipe yang berbeda.

(1) Tipe tindakan, yaitu suatu tindakan yang disengaja dengan konsekuensi di bawah kendali nomina. Jenis ini merupakan tipe 
fundamental dalam teori ketransitifan. Contoh: Desy menanam bunga.

(2) Tipe nontindakan, yang terdiri atas dua macam, yaitu (i) keadaan dan (ii) proses. Tipe keadaan adalah jenis ketransitifan yang secara sederhana mencirikan kepemilikan objek. Dalam tipe proses peristiwa atau perubahan yang terjadi terhadap sesuatu tanpa adanya kontrol. Contoh: Jalan itu lebar.

(3) Tipe mental, yaitu ketransitifan yang berbentuk proses mental atau keadaan mental. Contoh: Lusy kecewa mendengar berita itu.

\section{Nominalisasi}

Nominalisasi adalah sebuah proses gramatikal dalam pembentukan nomina dari jenis kata lain, biasanya berasal dari kategori verba atau adjektiva. Efek dari nominalisasi yaitu penghilangan pelaku tindakan. Nominalisasi dapat menghilangkan subjek karena dalam kalimat nominal, bukan lagi kegiatan atau tindakan yang ditekankan, tetapi peristiwa. Dalam kalimat yang menunjukkan kegiatan, subjek kalimat harus ditampilkan. Namun dalam kalimat yang menunjukkan peristiwa subjek atau pelaku tindakan tidak harus ditampilkan. Contoh:

(1) Polisi memukul demonstran di depan Gedung DPR kemarin.

(2) Pemukulan demonstran terjadi kemarin di depan Gedung DPR

\section{Pilihan Kalimat Aktif-Pasif}

Bentuk kalimat aktif dan pasif pada dasarnya adalah persoalan bagaimana sebuah bahasa mengekspresikan hubungan antara frasa verba dan nomina serta bagaimana pelbagai hal yang diasosiasikan dengan hubungan itu. Dalam kenyataannya, sebuah kalimat mungkin saja lebih sesuai dibandingkan dengan kalimat lain untuk situasi tertentu. Pertanyaannya adalah kalau sebuah ide atau gagasan dapat dikemukakan dengan aktif, mengapa penghasil teks lebih memilih bentuk pasif.
Pemilihan bentuk kalimat pasif oleh pemroduksi teks bisa saja bertujuan untuk menyembunyikan pelaku. Pelaku yang dalam bentuk kalimat aktif harus hadir, dalam kalimat pasif dapat dilesapkan. Kalimat pasif tanpa agen atau pelaku menurut Fairclough (dalam Santoso, 2012: 156) membiarkan kausalitas dan ketidakjelasan agen.

\section{Pilihan Kalimat Positif-Negatif}

Pada umumnya nilai pengalaman diekspresikan dalam kalimat positif. Pada kasus tertentu mungkin saja penutur atau penulis menggunakan kalimat negatif. Kalimat negasi terutama dipakai untuk menyangkal atau mengingkari pernyataan lawan tutur. Menurut Fairclough (dalam Santoso, 2017: 5) penulis menggunakan kalimat negatif sebagai sebuah cara untuk mengambil isu secara implisit yang sesuai dengan asersi-asersi positif. Negasi yang digunakan dapat berupa

(1) negasi "sesungguhnya",

(2) negasi "manipulatif", dan

(3) negasi "ideologis".

Bentuk negasi dapat dilakukan penulis untuk menyembunyikan apa yang ingin diekspresikan secara implisit. Negasi atau pengingkaran merupakan bentuk strategi wacana bagi penulis untuk tidak secara tegas dan eksplisit menyampaikan pendapat atau gagasannya kepada masyarakat.

\section{Modalitas}

Modalitas adalah fitur lingual yang menunjukkan tingkat komitmen atau sikap penutur (penulis) terhadap proposisi yang mereka tuturkan atau sikap terhadap pembaca. Pelbagai modalitas dalam bahasa tertentu dapat menginformasikan tingkat komitmen dan sikap penutur itu.

Ditinjau dari nilai fitur menurut Fairclough (dalam Santoso, 2012: 157) terdapat dua jenis modalitas, yaitu relasional dan ekspresif. Modalitas relasional adalah persoalan otoritas satu partisipan dalam hubungan dengan 
partisipan lainnya. Modalitas ekspresif adalah modalitas yang digunakan untuk menunjukkan otoritas penghasil teks yang berkenaan dengan kebenaran atau kemungkinan representasi realitas.

\section{METODE}

Pengumpulan data penelitian dilakukan dengan metode simak. Metode simak adalah metode pengumpulan data dengan cara menyimak penggunaan bahasa. Pada praktiknya penyimakan diwujudkan dengan penyadapan yang dilanjutkan dengan teknik catat (Sudaryanto, 1993: 133). Penggunaan bahasa yang disimak berupa wacana tajuk rencana harian Suara Merdeka. Wacana tersebut dicermati kemudian diseleksi dan diklasifikasi berdasarkan isi, relasi, dan posisi subjek yang terdapat dalam wacana tajuk rencana tentang konflik KPK dan Polri jilid II.Data dalam artikel ini diambil dari wacana tajuk rencana yang membahas konflik KPK vs Polisi Jilid II yang dimuat di harian Suara Merdeka pada bulan Januari-Februari 2015.

Kajian ini termasuk penelitian kualitatif. Penelitian kualitatif adalah metode penelitian suatu masalah yang tidak didesain atau dirancang menggunakan prosedur-prosedur statistik (Subroto, 2007: 5). Metode kualitatif lebih berdasarkan pada filsafat fenomenologis yang mengutamakan penghayatan (verstehen). Metode kualitatif berusaha memahami dan menafsirkan makna suatu peristiwa interaksi tingkah laku manusia dalam situasi tertentu menurut perspektif peneliti sendiri (Usman dan Akbar, 2011: 78).

\section{PEMBAHASAN}

Analisis dalam kajian ini dilakukan pada tujuh teks tajuk rencana harian Suara Merdeka yang membahas konflik KPK dan Polri jilid II. Dalam konflik tersebut terdapat partisipan baik individu, kelompok, atau institusi yang berkuasa terhadap partisipan yang lain. Kekuasaan tersebut terkait dengan kontrol dan pembatasan yang dilakukan oleh partisipan yang berkuasa terhadap partisipan lain yang tidak berkuasa. Hal tersebut tampak pada penggunaan gramatika yang terdapat dalam teks tajuk rencana.

\section{Gramatika Wacana Tajuk Rencana Kasus KPK vs Polri Jilid II}

Aspek gramatika dalam isi wacana berkaitan dengan dengan persoalan-persoalan klausa atau kalimat. Kajian terhadap aspek gramatika meliputi kajian terhadap pilihanpilihan: (a) ketransitifan, (b) nominalisasi, (c) pilihan kalimat aktif-pasif, (d) pilihan kalimat positif-negatif, dan (e) modalitas. Berikut ini pembahasan aspek gramatika pada wacana tajuk rencana Suara Merdeka yang membahas konflik KPK vs Polri Jilid II.

\section{Ketransitifan}

Dalam tajuk rencana Suara Merdeka salah satu aspek gramatika yang digunakan berupa ketransitifan. Penggunaan bentuk kalimat transitif ditemukan dalam tajuk rencana yang berjudul "KPK dalam Kepungan". Adapun bentuk transitif yang digunakan dalam tajuk rencana tersebut adalah tipe nontindakan, seperti tampak pada penggalan wacana berikut.

(1) Setelah penetapan status tersangka Komjen Budi Gunawan, KPK seolaholah berada dalam situasi terkepung tiga kekuatan yakni Istana Presiden, DPR, dan Polri. Kasus Budi Gunawan memang saat ini berada di tangan KPK setelah Presiden Joko Widodo "menggantung" nasib Budi Gunawan. Lembaga antirasuah itu harus dapat segera memberikan kepastian hukum. (TR “KPK dalam Kepungan")

Kalimat transitif pada penggalan wacana tersebut berupa kalimat "Setelah penetapan status tersangka Komjen Budi Gunawan, KPK seolah-olah berada dalam situasi terkepung tiga kekuatan yakni Istana Presiden, DPR, dan Polri". Kalimat transitif tipe nontindakan, terdiri atas kalimat transitif nontindakan keadaan dan 
proses. Kalimat pada contoh di atas termasuk ke dalam kalimat transitif nontindakan yang berupa keadaan, yaitu berada dalam situasi terkepung. Pembedaan penggunaan bentuk transitivitas membawa gambaran yang berbeda tentang peristiwa yang terjadi. Dengan menggunakan kalimat transitif tipe nontindakan keadaan, subjek KPK sebagai "korban" yang terzalimi(dimarjinalkan) tampak lebih menonjol. Penggunaan bentuk kalimat transitif nontindakan dimaksudkan untuk mendukung ideologi redaksi Suara Merdeka yang menempatkan institusi KPK sebagai "korban". Meskipun keadaan yang digambarkan oleh penulis tajuk rencana bahwa KPK berada dalam situasi terkepung hanya sebuah opini, hal tersebut tampak pada penggunaan kata seolah-olah dan pemilihan bentuk kalimat transitif.

Kalimat transitif juga ditemukan dalam tajuk rencana yang berjudul "Jangan Biarkan KPK Runtuh". Adapun bentuk transitif yang digunakan dalam tajuk rencana berupa proses mental, seperti tampak pada penggalan wacana berikut.

(2) Publik melihat peristiwa itu sebagai tindakan balas dendam Polri terhadap $\boldsymbol{K P K}$. Gerakan dan aksi solidaritas "selamatkan KPK" segera merebak di seluruh daerah di tanah air. Masyarakat menilai penangkapan Bambang Widjojanto bertujuan melemahkan KPK. Tuduhan yang disangkakan kepada Bambang dipandang terlalu mengadaada, karena tuduhan itu terkait dengan dugaan mobilisasi keterangan palsu di Mahkamah Konstitusi dalam sengketa Pilkada 2010. (TR “Jangan Biarkan KPK Runtuh")

Bentuk transitif dalam penggalan wacana di atas tampak pada kalimat berikut, "Publik melihat peristiwa itu sebagai tindakan balas dendam Polri terhadap KPK." Verba melihat pada kalimat tersebut bukan bermakna leksikal 'memandang atau memperhatikan', tetapi lebih bermakna 'menafsirkan atau memahami' yang merupakan proses mental. Adapun frasa peristiwa itu pada kalimat contoh mengacu pada peristiwa penangkapan Wakil Ketua Komisi Pemberantas Korupsi (KPK) Bambang Widjojanto oleh Bareskrim Polri. Dengan demikian, maksud redaksi dalam hal ini adalah publik menafsirkan penangkapan Bambang Widjojanto sebagai tindakan balas dendam Polri pada KPK. Penggunaan kedua bentuk transitif di atas dimaksudkan untuk membentuk konstruksi realitas yang diinginkan oleh redaksi.

\section{Nominalisasi}

Nominalisasi sering kali mereduksi makna kalimat dikarenakan dalam proses perubahan kalimat verbal menjadi kalimat nominal tersebut terjadi penghilangan agen atau pelaku (Fairclough, 2003:142). Ditinjau dari fungsinya dalam klausa, nominalisasi dapat menduduki fungsi sebagai: (1) partisipan, (2) proses, atau (3) keterangan. Nominalisasi terdapat dalam tajuk rencana yang berjudul "Pelumpuhan KPK Ancaman Serius", seperti tampak dalam penggalan wacana berikut.

(3) Semua pihak yang peduli dengan pemberantasan korupsi dan terwujudnya pemerintahan bersih di negeri ini, patut merasa risau dengan upaya pelumpuhan Komisi Pemberantasan Korupsi (KPK) yang sedang berlangsung saat ini. (TR "Pelumpuhan KPK Ancaman Serius")

Pada kalimat (3) nominalisasi terdapat pada penggunaan bentuk pemberantasan korupsi, pemerintahan, dan pelumpuhan. Namun, dari ketiga nominalisasi tersebut hanya pelumpuhan yang akan dibahas dalam penelitian ini karena bentuk tersebut relevan dengan kajian ini. Kata tersebut secara implisit menjelaskan adanya dominasi satu institusi terhadap institusi yang lain. Dalam hal ini institusi yang mendominasi adalah Polri, sedangkan institusi yang didominasi adalah KPK. Dengan menggunakan nominalisasi pelaku dominasi (pelumpuhan) dapat dilesapkan. Dengan lesapnya pelaku fokus pembicaraan beralih pada tindakan atau peristiwa, yaitu 
pelumpuhan. Peristiwa pelumpuhan inilah yang ingin ditonjolkan redaksi dalam wacana perseteruan KPK dan Polri sehingga menarik perhatian khalayak masyarakat agar bertindak menyelamatkan institusi KPK.

Kalimat pada contoh (3) disusun dengan urutan Partisipan+Proses+Keterangan. Nominalisasi pada kalimat tersebut menduduki fungsi sebagai keterangan, yakni dengan upaya pelumpuhan Komisi Pemberantasan Korupsi (KPK) yang sedang berlangsung saat ini. Susunan kalimat dengan nominalisasi keterangan seperti itu memberikan pemahaman bahwa bagian kalimat yang menduduki keterangan kurang memperoleh pementingan dibandingkan dengan bagian yang menduduki proses dalam kalimat. Dengan kata lain, frasa semua pihak yang peduli dengan pemberantasan korupsi dan terwujudnya pemerintahan bersih di negeri ini yang menduduki fungsi sebagai partisipan dan frasa patut merasa risau yang menduduki fungsisebagai proses dianggap lebih penting oleh redaksi Suara Merdeka dibandingkan dengan frasa dengan upaya pelumpuhan Komisi Pemberantasan Korupsi (KPK) yang sedang berlangsung saat ini yang menduduki fungtor keterangan. Hal tersebut menunjukkan bahwa redaksi Suara Merdeka ingin agar opini yang disampaikan mendapatkan dukungan dari khalayak atau masyarakat.

\section{Pilihan Kalimat Aktif-Pasif}

Kalimat aktif adalah kalimat yang mempunyai predikat berupa verba aktifatau verba yang menyatakan perbuatan yang dilakukan oleh subjek kalimat (Sugono, 2009: 118). Pilihan kalimat aktif pasif berkaitan dengan fokus pada peran pelaku atau sasaran dalam kalimat. Dalam kalimat aktif yang ditonjolkan atau difokuskan adalah peran pelaku, sedangkan dalam kalimat pasif yang menjadi fokus perhatian adalah peran sasaran. Dalam tajuk rencana yang berjudul "Setelah Calon Kapolri Jadi Tersangka" pilihan kalimat yang digunakan didominasi oleh kalimat aktif, seperti yang terlihat pada paragraf pertama tajuk rencana.
(4) Di luar perkiraan pemerintah maupun DPR, Komisi Pemberantasan Korupsi (KPK) menetapkan calon Kepala Kepolisian Republik Indonesia, Komisaris Jenderal Budi Gunawan, sebagai tersangka. (b) Setelah rekening gendut Budi dicurigai, KPK menemukan unsur pidana dan lebih dari dua alat bukti untuk meningkatkan ke tahap penyidikan. (c) Ketua KPK Abraham Samad mengklaim kasus ini telah diselidiki sejak Juli 2014. (d) Peristiwa ini menandaskan, betapa tanpa didesak oleh lembaga mana pun - termasuk oleh Indonesia Corruption Watch (ICW), PSHK, dan Lembaga Bantuan Hukum (LBH) Jakarta (yang tergabung dalam Koalisi Masyarakat Sipil)- KPK proaktif menjalankan tugas penegakan hukum tanpa kompromi. (TR "Setelah Calon Kapolri Jadi Tersangka")

Kalimat pertama pada penggalan teks di atas berupa kalimat aktif. Hal tersebut ditandai oleh verba yang mengisi fungsi predikat dalam kalimat tersebut, yaitu menetapkan. Hal yang sama tampak pada kalimat (b), (c), dan (d) yang unsur predikatnya ditempati oleh verba aktif berturut-turut menemukan, mengklaim, dan menjalankan. Yang menarik dari keempat kalimat tersebut, semua subjek atau pelaku perbuatan adalah KPK. Kalimat aktif mensyaratkan kehadiran subjek dalam kalimat. Dalam kalimat aktif fokus pembicaraan terletak pada pelaku. Hal itu menunjukkan bahwa redaksi memilih menggunakan bentuk kalimat aktif tersebut untuk menonjolkan agen atau pelaku dalam kalimat, dalam hal ini adalah institusi KPK.

Sebaliknya, dalam kalimat pasif fokus pembicaraan terletak pada sasaran. Selain itu, subjek atau pelaku tindakan dalam kalimat pasif dapat dilesapkan. Dalam tajuk rencana yang berjudul "Cukup Ampuhkah Sikap Jokowi?" pilihan kalimat yang digunakan berupa kalimat pasif, seperti tampak pada contoh berikut. 
(5) Presiden diingatkan agar lebih memperhitungkan kehendak rakyat ketimbang mengikuti kemauan orangorang atau kekuatan politik yang mendikte. (TR "Cukup Ampuhkah Sikap Jokowi?")

Dalam kalimat pasif peran sasaran dalam kalimat lebih difokuskan, sedangkan kehadiran frasa agen (pelaku) dapat disamarkan. Pada kalimat di atas tidak jelas siapa pelaku yang mengingatkan presiden meskipun hal tersebut dapat diketahui dalam wacana. Pemilihan bentuk kalimat pasif dimaksudkan untuk menonjolkan subjek kalimat (peran sasaran) dalam hal ini ditempati oleh presiden. Figur presiden dikedepankan sebab dalam pandangan redaksi Suara Merdeka presiden merupakan figur sentral dalam penyelesaian konflik antara KPK dan Polisi. Namun, sikap yang diambil oleh presiden dalam konflik tersebut dianggap tidak tegas.

Pilihan bentuk kalimat pasif juga digunakan dalam tajuk rencana yang berjudul "Rakyat, Partai Politik, dan Presiden" seperti tampak pada penggalan teks berikut.

(6) Separuh lebih posisi di kabinet diisi dengan orang-orang politik yang memiliki hubungan dengan Ketua Umum Partai Demokrasi Indonesia Perjuangan (PDIP) serta partai-partai pendukung dalam pemilihan presiden. (TR "Rakyat, Partai Politik, dan Presiden")

Dalam kalimat pasif kehadiran frasa agen (pelaku) dapat disamarkan. Ketiadaan agen pada kalimat pasif sekali lagi menyebabkan kausalitas dan agen tidak jelas. Pada kalimat di atas predikat yang ditempati verba diisi menimbulkan ketidakjelasan agen, yaitu siapa yang mengisi dalam arti 'menduduki' jabatan di kabinet atau siapa yang mengisi dalam arti 'memilih' kabinet. Untuk mengacu pada makna yang kedua (siapa yang mengisi dalam arti 'memilih' kabinet) pelaku, yaitu presiden seharusnya ditampilkan dalam kalimat supaya jelas, seperti kalimat berikut "Separuh lebih posisi di kabinet diisi presiden dengan orang-orang politik yang memiliki hubungan dengan Ketua Umum Partai Demokrasi Indonesia Perjuangan (PDIP) serta partai-partai pendukung dalam pemilihan presiden." Pada kalimat yang terdapat di teks sosok presiden tidak ditampilkan. Pelesapan agen tidak dilakukan untuk menyamarkan pelaku, tetapi lebih dikarenakan sosok presiden menurut redaksi berada pada posisi yang lemah. Presiden dipandang tidak mempunyai kekuasaan untuk memilih sosok menteri yang sesuai dengan idealismenya, yaitu kabinet yang ramping dan profesional. Hal tersebut disebabkan adanya kepentingan partai yang telah berjasa mengantarkan Jokowi ke kursi presiden.

Sementara itu, pelaku yang bermakna 'orang yang menduduki jabatan di kabinet', yang menjadi pelaku adalah orang-orang politik yang memiliki hubungan dengan Ketua Umum Partai Demokrasi Indonesia Perjuangan (PDIP) serta partai-partai pendukung dalam pemilihan presiden. Penggunaan bentuk kalimat pasif dimanfaatkan redaksi Suara Merdeka untuk menunjukkan ketidakberdayaan presiden dalam memilih pembantu-pembantu sesuai dengan idealismenya.

\section{Pilihan Kalimat Positif Negatif}

Pada umumnya nilai pengalaman diekspresikan dalam kalimat positif. Pada kasus tertentu mungkin saja penutur atau penulis menggunakan kalimat negatif. Kalimat negasi terutama digunakan untuk menyangkal atau mengingkari pernyataan lawan tutur. Menurut Fairclough (dalam Santoso, 2017: 5) penulis menggunakan kalimat negatif sebagai sebuah cara untuk mengambil isu secara implisit yang sesuai dengan asersi-asersi positif.

Aspek gramatika yang digunakan dalam tajuk rencana Suara Merdeka adalah bentuk kalimat positif-negatif. Dalam teks tajuk rencana yang berjudul "Titah Ibu Kandung" digunakanpilihan kalimat negatif, seperti tampak pada penggalan wacana berikut.

(7) Sebagai ibu kandung KPK, komitmen Megawati terhadap pemberantasan korupsi tentu tidak diragukan lagi. 
Mengusung slogan partainya wong cilik, PDIP menjadi penggerak dan pembela KPK saat berada dalam berbagai tekanan di era pemerintahan Susilo Bambang Yudhoyono. (TR “Titah Ibu Kandung”)

Kalimatnegatifdalampenggalan wacana di atas, yaitu "Sebagai ibu kandung KPK, komitmen Megawati terhadap pemberantasan korupsi tentu tidak diragukan lagi." Negasi dalam kalimat tersebut ditandai oleh pemarkah tidak meskipun dalam kalimat contoh disebutkan bahwa komitmen Megawati terhadap pemberantasan korupsi tentu tidak diragukan lagi, tetapi dalam paragraf lain redaksi menyebutkan hal-hal yang meragukan komitmen tersebut, sebagaimana tampak pada penggalan wacana berikut.

(8) Tapi, ikatan biologis dengan politis itu berbeda. Kerekatan sedarah memiliki energi psikologis luar biasa. Peribahasa "kasih ibu sepanjang jalan, kasih anak sepanjang penggalan" tidak otomatis berlaku dalam politik.

Perekat ikatan politis itu kepentingan. Saat kepentingan tak bertaut, ikatan bisa luput atau terlepas, bahkan putus, saling membenci, memfitnah atau saling menghancurkan. Drama dalam kehidupan politik acap kali melahirkan riak-riak kecil hingga gelombang besar yang bisa menghempaskan lawan atau kawan. Maka tak ada jaminan, ketika KPK dilahirkan ibunda Megawati lantas akan terus dalam dekapan, dilindungi atau dibela. Publik pun akan memberi tafsir beragam atas serangan politikus PDIP terhadap KPK. (TR “Titah Ibu Kandung”)

Dari penggalan wacana di atas tampak halhal yang meragukan komitmen tersebut, yaitu Maka tak ada jaminan, ketika KPK dilahirkan ibunda Megawati lantas akan terus dalam dekapan, dilindungi atau dibela. Publik pun akan memberi tafsir beragam atas serangan politikus PDIP terhadap KPK.Dari pernyataan tersebut dapat disimpulkan komitmen Megawati terhadap pemberantasan korupsi diragukan karena tidak melindungi atau membela KPK ketika mendapat tekanan. Bahkan, serangan-serangan terhadap KPK dilakukan oleh kader-kader partai yang dipimpin Megawati sendiri, yaitu Sugianto Sabran dan Pelaksana Tugas Sekretaris Jendral PDIP, Hasto Kristiyanto yang melaporkan pimpinan KPK ke Bareskrim Polri. Dengan demikian, penggunaan bentuk negatif pada kalimat, "Sebagai ibu kandung KPK, komitmen Megawati terhadap pemberantasan korupsi tentu tidak diragukan lagi" merupakan sebuah ironi. Ungkapan tersebut tidak dimaksudkan untuk memuji Megawati. Sebaliknya, ungkapan tersebut sebenarnya menggambarkan realitas yang bertentangan.

\section{Modalitas}

Dalam tajuk rencana yang membahas perseteruan KPK dan Polri jilid II hubungan antarpartisipan terjalin antara Redaksi Suara Merdeka dan Presiden Hubungan antara presiden dan harian Suara Merdeka (dalam hal ini direpresentasi oleh redaksi sebagai penulis tajuk rencana) terjadi ketika penulis tajuk rencana memberikan kritik dan saran terhadap presiden. Kritik terhadap presiden dilakukan dengan memanfaatkan modalitas yang menyatakan "saran". Hal itu tampak pada penggunaan kata sebaiknya, seperti tampak pada kutipan berikut,

(9) Peristiwa ini juga mengisyaratkan betapa Presiden Jokowi atau DPR sebaiknya melibatkan PPATK dan KPK setiap hendak memilih pejabat pejabat tinggi agar bisa diketahui apakah mereka bersih dari korupsi atau tidak. (TR "Setelah Calon Kapolri Jadi Tersangka”)

"Peristiwa ini juga mengisyaratkan betapa Presiden Jokowi atau DPR sebaiknya melibatkan PPATK dan KPK setiap hendak memilih pejabat-pejabat tinggi agar bisa diketahui apakah mereka bersih dari korupsi atau tidak." Kritik tersebut menyebutkan agar presiden dalam memilih pejabat tinggi yang bersih dari korupsi untuk melibatkan PPATK dan KPK. Meskipun dalam tajuk rencana juga disebutkan bahwa 
dalam pemilihan calon kapolri, presiden juga telah melibatkan Komisi Kepolisian Nasional (Kompolnas). Kritik dan saran lain tampak pada kutipan berikut.

(10) Kita tahu Presiden Jokowi terkejut dan menganggap kasus Budi telah selesai lewat klarifikasi Pusat Pelaporan dan Analisis Transaksi Keuangan (PPATK) pada 2010. Tak ada juga tandatanda rekening gendut Budi bakal dipersoalkan di jalur hukum. Tentu terkejut saja, tidak cukup. Jokowi harus segera merespons persoalan ini agar tak dianggap sebagai presiden yang antipemberantasan korupsi. (TR "Setelah Calon Kapolri Jadi Tersangka")

Dalam penggalan wacana tersebut Presiden Jokowi dideskripsikan terkejut dengan penetapan Komjen Budi Gunawan sebagai tersangka oleh KPK. Dalam kritiknya, Suara Merdeka menganggap terkejut saja tidak cukup, tetapi presiden harus merespons persoalan tersebut dengan baik agar tidak dianggap sebagai presiden yang antipemberantasan korupsi. Penggunaan modalitas harus yang menyatakan "perintah" menunjukkan ekspresi mengarahkan pada suatu tindakan tertentu yang merupakan bentuk dominasi redaksi terhadap presiden.

\section{Penjelasan}

Dari pembahasan penggunaan gramatika dalam wacana tajuk rencana Suara Merdeka di atas, tampak sekali keberpihakan redaksi terhadap institusi KPK. Dalam hal ini, redaksi ingin menyuarakan pihak yang dimarjinalkan oleh kekuasaan, yaitu institusi KPK. Dengan berpihak pada KPK, redaksi Suara Merdeka ingin menempatkan posisinya sebagai institusi yang propemberantasan korupsi. Dengan memihak institusi KPK secara tidak langsung redaksi telah memperjuangkan keadilan bagi masyarakat. Selain itu, sebagai pers Suara Merdeka mempunyai fungsi sebagai media kontrol sosial sehingga ketika terjadi ketimpangan, ketidakadilan, ataupun dominasi terhadap kaum yang tertindas, Suara Merdeka tampil sebagai penyeimbang.

\section{PENUTUP}

Redaksi Suara Merdeka dalam menulis tajuk rencana memanfaatkan gramatika untuk membentuk konstruksi realitas yang diinginkan. Realitas tersebut dibentuk dengan menggunakan ketransitifan, nominalisasi, pemasifan, penegasian, dan modalitas. Pemilihan transitivitas tertentu dimaksudkan untuk menempatkan institusi KPK seolaholah sebagai korban (pihak yang dizalimi). Di lain pihak, untuk mendeskripsikan institusi Polri sebagai pihak yang mendominasi redaksi menggunakan nominalisasi. Selain itu, redaksi juga memanfaatkan nominalisasi untuk mendapat dukungan dari khalayak (pembaca) untuk mendukung institusi KPK. Bentuk kalimat aktif digunakan redaksi untuk mendeskripsikan institusi KPK secara positif. Sebaliknya, redaksi menggunakan kalimat pasif, kalimat negatif, dan modalitas untuk memarjinalkan sosok presiden. Dengan demikian, ideologi harian Suara Merdeka dalam menulis tajuk rencana yang membahas konflik KPK vs Polri jilid II tidak objektif karena cenderung berpihak pada institusi KPK.

\section{DAFTAR PUSTAKA}

Darma, Yoce Aliah (2009), Analisis Wacana Kritis, Bandung: Yrama Widya.

Fairclough, Norman, (2003), Language and Power: Relasi Bahasa, Kekuasaan dan Ideologi, Malang: Boyan.

Mardikantoro, Hari Bakti (2014), Analisis Wacana Kritis pada Tajuk (Anti)Korupsi di Surat Kabar Berbahasa Indonesia, Jurnal LITERA, Volume 13, Nomor 2, Oktober 2014, Yogyakarta: UNY, hh. 215-225.

Rambe, Patient (2012), Critical Discourse Analysis of Collaborative Engagement in Facebook Postings, Australasian Journal 
of Educational Technology, 2012, 28(2), page 295-314.

Rokhman, Fathur dan Surahmat (2016), Politik Bahasa Penguasa, Jakarta: Kompas Media Nusantara.

Santosa, Anang (2012), Studi Bahasa Kritis Menguak Bahasa Membongkar Kuasa, Bandung: Mandar Maju.

Santoso, Anang,(2017) Penggunaan Gramatika dalam Wacana Politik",Jurnal Verba lingua Volume 4, Nomor 1, Juni 2017, Kupang: Kantor Balai Bahasa Nusa Tenggara Timur, hh. 1-8.

Sudaryanto (1993), Metode dan Aneka Teknik Analisis Bahasa: Pengantar Penelitian Wahana Kebudayaan secara Linguistis, Yogyakarta: Duta Wacana Uuniversity Press.

Sugono, Dendy (2009), Mahir Berbahasa Indonesia dengan Benar, Jakarta: Gramedia Pustaka Utama.
Sugiyono (2012), Metode Penelitian Kuantitatif, Kualitatif dan $R \& D$, Bandung: Alfabeta.

Sutrisno, Endro (2012), Editorial Media Indonesia dan Tajuk Rencana Kompas dalam Analisis Wacana Kritis: Jurnal Fakultas Bahasa dan Seni, Volume 03, Nomor 1,Madiun: IKIP PGRI,hh. 1-24.

Tahmasbi, Soheila and Sasan Ghorgani Khalkajeh (2013), Critical Discourse Analysis: Iranian Banks Advertisements, Asian Economic and Financial Review, 2013, 3 (1),page 124-145.

Van Dijk, Teun (2001), Principles of Critical Discourse Analysis, Dalam Wetherel, Margaret et al. 2001, Discourse Theory and Practice, London: Sage Publications. 